\title{
Statyba
}

\section{BUILDING ENTERPRISES INDUSTRIAL STRUCTURE'S OPTIMISATION}

\section{R. Ginevičius \& S. Čirba}

To cite this article: R. Ginevičius \& S. Čirba (1996) BUILDING ENTERPRISES INDUSTRIAL STRUCTURE'S OPTIMISATION, Statyba, 2:5, 80-91, DOI: 10.1080/13921525.1996.10531551

To link to this article: https://doi.org/10.1080/13921525.1996.10531551

册 Published online: 26 Jul 2012.

Submit your article to this journal 5

Џ Article views: 56 


\title{
STATYBOS İMONIŲ GAMYBINĖS STRUKTŪROS OPTIMIZAVIMAS
}

\author{
R.Ginevičius, S.Čirba
}

\section{Ivadas}

Perèjimas ị rinkos ekonomiką pakeitė statybos ịmonių (SI) komercinès-ūkinès veiklos sąlygas. Konkurso keliu formuojama gamybiné programa gali svyruoti gana plačiose ribose tiek savo dydžiu, tiek ir darbo sąnaudu struktūra. Aukštų rezultatı̨ tokiu atveju galima tikètis tik tada, jeigu SI sugebès atitinkamai reaguoti ir prisitaikyti prie besikeičiančios gamybinès aplinkos. Iš kitos pusès nerealu ir beprasmiška siekti visiško ir pastovus statybos imonès organizacinès valdymo struktūros (OVS) atitikimo vis naujai ir naujai situacijai.

Siekti ükinès-komercinès veiklos stabilumo tokiomis prieštaringomis sąlygomis galima tik turint atitinkamą organizacijos ịvaizdị. Efektyviai dirbančios SI išryškino principinị gamybinès struktūros (GS) modelį, pasižymintị lankstumu ir leidžiantị prisitaikyti prie pastoviai gana plačiose ribose besikeičiančios situacijos. Tokios organizacijos GS sudaro dvi principinès dalys - pastovi ir kintama. Pirmoji - tai gamybinès struktūros esmè, "karkasas", užtikrinanti SI potencialą, aukštus darbų atlikimo tempus, kokybę bei pačios organizacijos profesionalumą. Antroji - tai buferis, kompensuojantis gamybinès programos masto ir struktūros svyravimus.

Tokiu atveju labai svarbiu tampa organizacijos pastovios dalies arba "branduolio" klausimas. Jeigu jis bus per didelis, tai tam tikrais laiko tarpais liks neapkrautas, jeigu per mažas - kris statybos imonès darbo efektyvumas. Taigi, galima kalbèti apie optimalu jo dydi viso organizacijos dydžio atžvilgiu.

\section{Statybos ịmonès gamybinès struktūros pritaikymo gamybinei programai uždaviniai ir galimybès}

Statybos ịmonès gamybinès struktūros pritaikymas naujai jos situacijai iš esmès reiškia atitinkamą padalinių skaičiaus ir sąstato pakitimą (1 pav.) [1]. Statybos ir montavimo darbų apimtys, formuojamos konkurso keliu, gali svyruoti labai plačiose ribose. Tai turetu atsiliepti ir organizacijos dydžiui. Jeigu tokiomis sąlygomis siekti pastovaus ir visiško gamybinès struktūros atitikimo gamybinei programai, statybos imonę visą laiką reikètų reorganizuoti, kas yra nerealu ir beprasmiška. GS būdinga inercija, t.y. siekimas kiek galima ilgiau išlaikyti nekintamą struktūrą, nes tik tokiu atveju įmanomas našus ir ritmingas darbas $[1,2,3]$.

Šiandieną statybos imonių, siekiančių komercinès-ūkinès veiklos stabilumo, organizacinès valdymo struktūros yra labai ịvairios. Pavyzdžui, kai kurios savo gamybinį padalinių neturi iš viso. Palyginti nedidelis jų valdymo aparatas ieško užsakymų, sudaro kontraktus, o ju vykdymui generalinès rangos sutarčių pagrindu pritraukia visas būtinas statybos organizacijas - tiek bendrastatybines, tiek specializuotas.

Kitas kraštutinumas - siekimas sukurti uždarą sistemą, t.y. savo jègomis atlikti visus statybos bei montavimo darbus, ir tuo būdu kuo mažiau priklausyti nuo supančios aplinkos.

Nei vienas, nei kitas SI organizacinès valdymo struktūros variantas nèra perspektyvus. I juos galima žiūrèti kaip ị laikiną formą, atsiradusią, siekiant prisitaikyti prie dabartinès ūkinès-ekonominès situacijos, kai rinka dar pilnai nesusiformavusi, kai dar nepilnai veikia istatymai ir t.t. Abu aptarti OVS variantai neefektyvūs, nes pilnai veikiančios rinkos sąlygomis, jie iš principo neleidžia pasiekti aukštu galutinių komercinèsūkines veiklos rezultatų. Pirmu atveju taip yra dèl to, kad savo jégomis darbai neatliekami iš viso, taigi nèra galimybių mažinti savikainą, sudėtingas statybos dalyvių, siekiančių skirtingų tikslų, valdymas ir darbo kordinavimas. Visi jie pritraukti subrangovy teisèmis ir todèl jiems reikia moketi ne tik už pagamintą produkcija, 


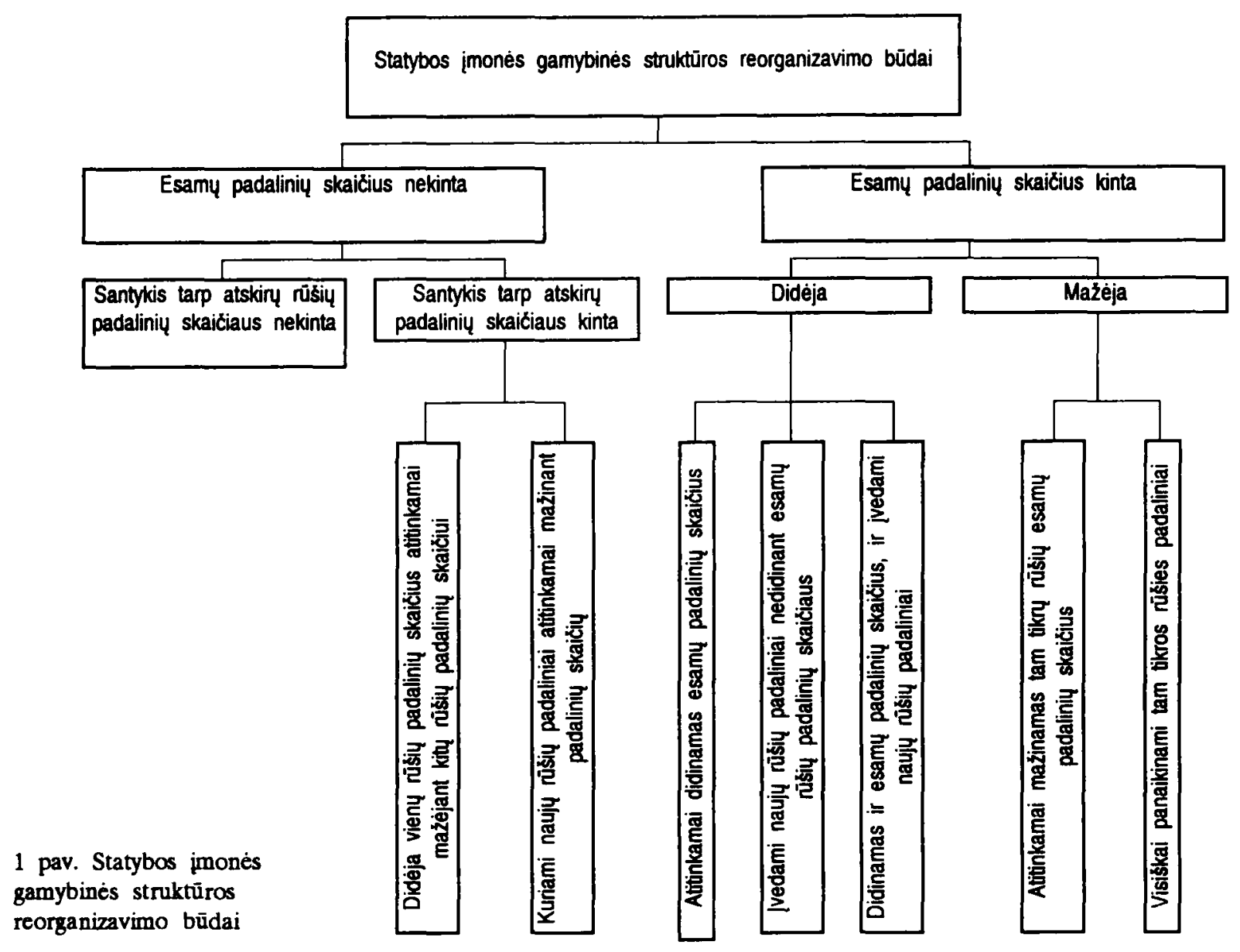

bet ir padengti ị sutartị ikalkuliuotą pelną ir pan.

Kitu atveju, statybos i̇moné, siekdama savo sudètyje turèti visus, tame tarpe ir specializuotus, padalinius, dèl darbo apimčių svyravimų ne visada galès juos pilnai apkrauti, labai padidès išlaidos specialioms mašinoms, mechanizmams, j̇rangai ịsigyti ir išlaikyti. Visa tai vèlgi atsilieps pelno dydžiui.

Todèl reikia manyti, kad racionalaus SỊ organizacinès valdymo struktūros varianto reikia ieškoti atitinkamai derinant abu aptartus atvejus, t.y. jos turi turèti branduoli, sudarytą iš nuosavy pastoviai veikianči gamybiniy padalinių (bendrastatybiniy ir specializuotų), aprūpintų siuolaikine statybos technika ir laikinų padalinių, kurių paskirtis būtų vykdyti SI nebūdingus specializuotus darbus, o taip pat padidèjusios bendrastatybinių darby apimtis. Pastaruosius gali atlikti tiek nuosavi, tiek ir pritraukti padaliniai (2 pav.).

Taigi, dabartiné statybos įmonè nuo buvusios skiriasi tuo, kad atsirado nuosavi laikinai veikiantys gantybiniai padaliniai (LP). SI veiklos analizè rodo, kad tai kaip taisyklè, specializuotos grandys, atliekančios bendrastatybinius darbus. LP - tai padalinys, suformuotas iš žmonių, su kuriais sutartis darbui statybos įmoneje sudaryta arba terminuotam laikui, arba tam tikrai darbu apimčiai (pavyzdžiui, vieno objekto statybai) atlikti. Sutartis, terminui pasibaigus, gali būti pratęsiama arba ne. Jeigu aplinkybès Sİ klostosi palankiai, dalis likviduojamo padalinio žmonių, parodžiusių aukštą kvalifikaciją, gali būti priimta pastoviam darbui.

2 pav. rodo, kokie galimi statybos įmonès gamybinès struktūros variantai (1 lentelè).

Statybos įmonè, siekdama išsaugoti konkurentabilumą, turetu stengtis išlaikyti kuo didesnị savo potencialą, kuris priklauso nuo pastoviai joje dirbančiu specialistų, darbininkų, technikos, turimų dirbtuvių, sandèlių ir pan. [2]. Iš kitos pusès šis potencialas negali būti per didelis, nes dèl darbų apimčiu svyravimo tam tikrais laiko tarpais, jis gali būti nepilnai apkrautas darbu (3 pav.).

Iš 3 pav. matome, kad, ieškant optimalaus statybos įmonès gamybinių padalinių sąstato, reikia nustatyti 


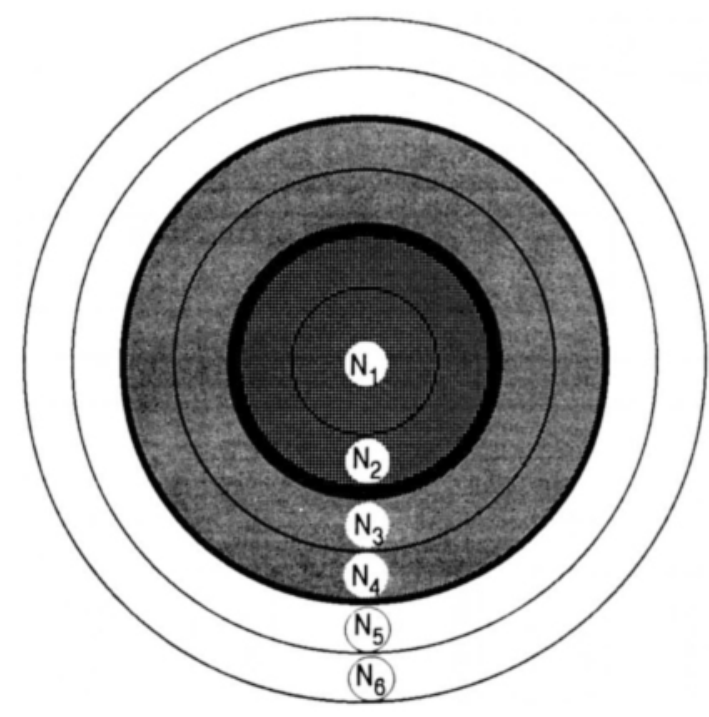

2 pav. Statybos imonès gamybinès struktūros principine sudetis darbams, atliekamiems generaline ranga $\left(N_{1}\right.$ - nuosavi pastoviai veikiantys bendrastatybiniai padaliniai; $N_{2}$ - nuosavi pastoviai veikiantys specializuoti padaliniai; $N_{3}$ - nuosavi laikini bendrastatybiniai padaliniai; $N_{4}$ - nuosavi laikini specializuoti padaliniai; $N_{5}$ - pritraukti bendrastatybiniai padaliniai; $N_{6}-$ pritraukti specializuoti padaliniai)

1 lentelè. Statybos jmonès gamybinès struktūros sudètinès dalys

\begin{tabular}{ll}
\hline $\begin{array}{l}\text { Statybos ịmonès gamybinès struktūros sudètinių } \\
\text { dalių sąlyginis pavadinimas }\end{array}$ & $\begin{array}{l}\text { Statybos imonès gamybinés } \\
\text { struktūros variantą atitinkantis } \\
\text { padalinių sąstatas }\end{array}$ \\
\hline $\begin{array}{l}\text { Statybos jmonès gamybinès struktūros pastovioji dalis (SI "branduolys") } \\
\text { Statybos jmonès gamybinès struktūros nuosava nepastovioji dalis }\end{array}$ & $N_{1}+N_{2}$ \\
$\begin{array}{l}\text { Statybos jmonès gamybinès struktūros pritraukta nepastovioji dalis } \\
N_{3}+N_{4}\end{array}$ & $N_{5}+N_{6}$ \\
$\begin{array}{l}\text { Statybos jmonès gamybinè struktūra darbams, atliekamiems } \\
\text { savo jègomis (pilna laikina nuosava gamybinè struktūra) }\end{array}$ & $\left(N_{1}+N_{2}\right)+\left(N_{3}+N_{4}\right)$ \\
$\begin{array}{l}\text { Statybos jmonès gamybinè struktūra darbams, atliekamiems } \\
\text { generaline ranga (pilna laikina gamybinè struktūra) }\end{array}$ & $\left(N_{1}+N_{2}\right)+\left(N_{3}+N_{4}\right)+\left(N_{5}+N_{6}\right)$ \\
\hline
\end{tabular}

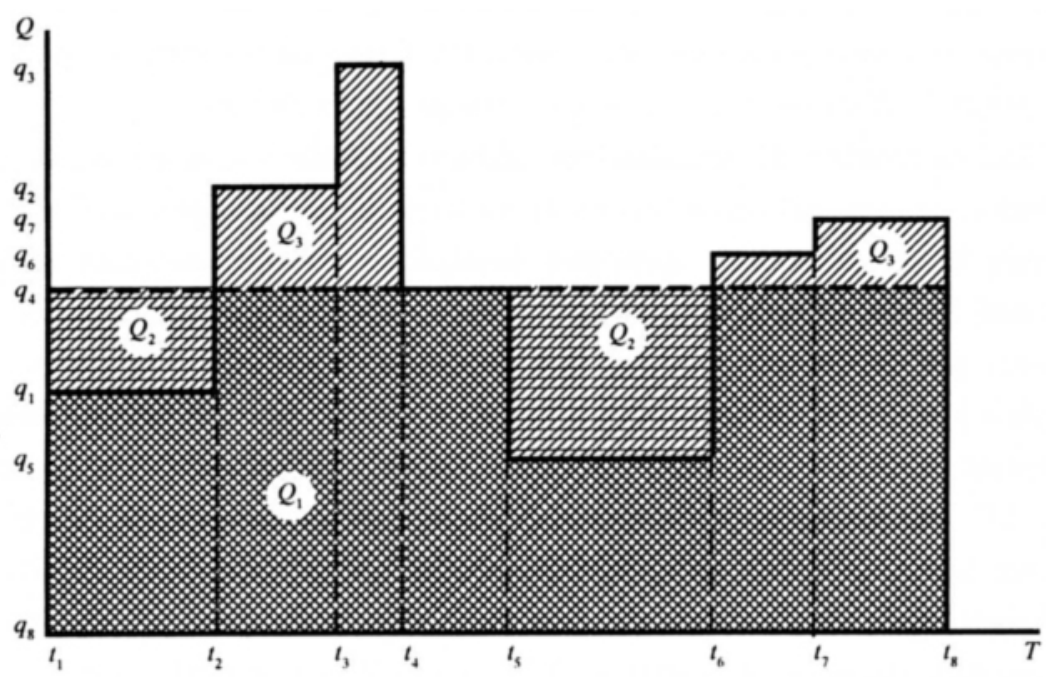

3 pav. Statybos jmonés gamybinès programos ir GS galimi nesąryšiai ( $T$ - nagrinejamas SI darbo laikotarpis; $t_{1}, t_{2}, \ldots$, $t_{8}$ - laiko momentai, kada kinta gamybinès programos dydis; $Q$ - darbu apimtys; $q_{1}, q_{2}, \ldots q_{8}$ - darbu apimtys, atitinkančios laiko momentus $t_{1}, t_{2}, \ldots, t_{8} ; q_{o p t}$ - optimali darby apimtis, kurią turety vykdyti nuosavi pastoviai veikiantys gamybiniai padaliniai $\left(N_{1}+N_{2}\right) ; Q_{1}$ - bendra darbų apimtis, kurią per laikotarpi $T$ turetų atlikti nuosavi pastoviai veikiantys padaliniai (SI "branduolys"); $Q_{2}$ - bendra darbų apimtis, kuria per laikotarpi $T$ nuosavi pastoviai veikiantys padaliniai bus neapkrauti; $Q_{3}$ - darbu apimtis, kurią turétu atlikti pritraukti ar nuosavi laikini padaliniai) 
šiuos santykius:

$$
k_{1}=\frac{Q_{1}}{Q_{2}} ; \quad(1) ; \quad k_{2}=\frac{Q_{3}}{Q_{1}} ; \quad(1 \mathbf{a}) ; \quad k_{3}=\frac{Q_{2}+Q_{3}}{Q_{1}} ; \quad \text { (2) } \quad k_{4}=\frac{\left(Q_{2}+Q_{3}\right)-Q_{4}}{Q_{1}}
$$

čia $Q_{4}$ - darbų apimtis, kurią atlieka pritraukti gamybiniai padaliniai $\left(N_{5}+N_{6}\right)$.

Iš visų nurodytu santykių svarbiausias yra (3), nes būtent jį nagrinèjant galima surasti optimalią darbų apimtị, kurią turètų atlikti statybos įmonès "branduolys".

\section{Statybos įmonès gamybinès struktūros "branduolio" optimalaus dydžio nustatymas}

Sakykime, kad $Q_{i}-i$-s darbų rūšies (mūro, tinkavimo ir pan.) apimtys $(i=1,2,3, \ldots, n)$, o $F_{i}(q)$ - ju pasiskirstymo funkcija. Jeigu $Q_{i}$ yra diskretinis atsitiktinis dydis, tai jo reikšmés gali būti pateiktos taip (2 lentelè):

2 lentelè. Statybos jmonès darbų apimčių, numatomų atlikti per nagrinejamą laikotarpi pasiskirstymas

\begin{tabular}{llllll}
\hline$Q_{i}$ & $q_{i 1}$ & $q_{i 2}$ & $q_{i 3}$ & $\ldots$ & $q_{i m_{i}}$ \\
\hline$P_{i}$ & $p_{i 1}$ & $p_{i 2}$ & $p_{i 3}$ & $\ldots$ & $p_{i m_{i}}$ \\
\hline
\end{tabular}

2 lenteleje dydis $p_{i j}\left(1 \leq j \leq m_{i}\right)$ reiškia tikimybę, kad per nagrinejjamą laikotarpi bus atlikta darbų apimtis $q_{i j}$. Tiek $q_{i j}$, tiek jam atitinkantys $p_{i j}$ gali būti gauti pasitelkus statybos įmonès, kuriai atliekami skaixiavimai, ekspertus.

Ivesime šiuos sąlyginius pažymèjimus:

$y_{i}$ - $i$-s rū̌ies darbu, kuriuos tures atlikti SI "branduolio" atitinkami padaliniai per nagrinejjamą laikotarpi, apimtis;

$a_{i}$ - pelnas, kurị gaus SI, jeigu $i$-s nuosavas pastoviai veikiantis padalinys atliks $i$-s rüšies darbų vienetą.

$b_{i}$ - pelnas, kuri gaus SI, jeigu $i$-s rūšies darby vienetą atliks nuosavas laikinas padalinys;

$\bar{a}_{i}$ - nuostoliai, kuriuos patirs SI dèl to, kad, atliekant i-s rūšies darbus, atitinkamai "branduolio" padaliniai bus nepilnai apkrauti.

Plačiau aptarsime dydį $\bar{a}_{i}$. Statybos įmoné tam tikrais laiko tarpais sumažejus darbų apimtims (3 pav., $t_{1}-t_{2}, t_{5}-t_{6}$ ), negalès pilnai apkrauti nuosavu pastoviai veikiančių padalinių. Jeigu jie nedirbtu iš viso, SI turètų gryną nuostoli. Išeitis surandama į gamybinę programą ijungus taip vadinamus "nenaudingus" objektus. Tai statybos, nekeliančios griežtu trukmès, kokybès ir pan. reikalavimų. Dirbdami juose, minèti padaliniai imonei neduoda pelno, bet neatneša ir nuostolio. Be to tai poligonas apmokyti ir išbandyti naujus darbuotojus.

Savo skaičiavimuose priimsime, kad pelnas $c_{i}$, gaunamas tokiuose objektuose, yra žymiai mažesnis palyginus su $a_{i}$, t.y. $\quad c_{i} \approx 0$. Jeigu $c_{i}>0$, tai priimsime, $\operatorname{kad} a_{i}=-c_{i}$.

Dabar jau galima suformuluoti uždavinį: kokią darbų apimtị per nagrinejamą laikotarpị turi atlikti statybos įmonès nuosavi pastoviai veikiantys padaliniai, kad gautas pelnas būtų didžiausias. Tuo pačiu nustatysime $\mathrm{SI}$ "branduolio" optimaly dydį.

Pirmiausia patikslinsime iš 3 pav. išplaukiančias sąlygas:

1) jeigu $i$-s rūšies darbu apimtis $y_{i}$ per nagrinèjamą laikotarpi $T$ bus mažesnè palyginti su ta, kurią galetu atlikti nuosavi pastoviai veikiantys padaliniai, tai reikš, kad jie bus nepilnai apkrauti ir turès dirbti minètuose "nenaudinguose" objektuose;

2) jeigu $i$-s rūšies darbų apimtis $y_{i}$ per nagrinejjamą laikotarpi $T$ bus didesné palyginti su ta, kuria galetu atlikti nuosavi pastoviai veikiantys padaliniai, t.y. $\bar{y}_{i}>y_{i}$, statybos įmoné turi suformuoti nuosavus laikinus gamybinius padalinius.

Priimsime, kad pagrindinis jų skiriamasis bruožas yra tas, kad, palyginti su "branduolio" padaliniais, 
dirbančiujų kvalifikacija, darbo našumas, taigi ir jų gaunamas pelnas, yra mažesni.

Kitaip tariant, jeigu $y_{i}=\bar{y}_{i}$ ir $Q_{i}=\bar{q}_{i}$ (čia $q_{i}$ yra vienas iš antros lentelès skaičių), tai pelną $d_{i}$ padalinių, atliekančiu $i$-s rūšies darbus, bus galima skaičiuoti pagal formulę:

$$
d_{i}=\left\{\begin{array}{lll}
a_{i} \bar{q}_{i}-\left(\bar{y}_{i}-\bar{q}_{i}\right) \bar{a}_{i}, \text { jeigu } & \bar{q}_{i} \leq \bar{y}_{i}, \\
a_{i} \bar{y}_{i}+b_{i}\left(\bar{q}_{i}-\bar{y}_{i}\right), \text { jeigu } & \bar{q}_{i}>\bar{y}_{i} .
\end{array}\right.
$$

Darbų apimtys $Q_{i}(1 \leq i \leq n)$ paprastai yra atsitiktinis dydis, todèl ir pelną $d_{i}$ nustatysime su tam tikra tikimybe, t.y. jeigu $\bar{q}_{i}=q_{i s}\left(1 \leq s \leq m_{i}\right)$, tai pelną $d_{i}$ turésime su tikimybe $p_{i s}$. Kitaip sakant, koks bus pelnas $d_{i}$, iš anksto tiksliai nustatyti negalèsime, tačiau nurodysime galimus jo variantus su atitinkamomis tikimybèmis. Iš to seka, kad galime kalbèti tik apie su didžiausia tikimybe laukiamą pelną (žinoma, šiuo atveju ir rizikos laipsnis bus didžiausias) arba apie vidutini pelną.

Pirmuoju atveju iš 2 lentelès parenkame didžiausią tikimybę (didžiausią antros eilutès skaičių). Prièmus, kad ji lygi $p_{i s}$, gausime, $\operatorname{kad} \bar{y}_{i}=q_{i s}$.

Antruoju atveju, kai $q_{i s_{i}} \leq y_{l} \leq q_{i s_{i+1}}$, remiantis vidurkio skaičiavimo taisykle [4], gausime, kad vidutinis pelnas $D$ bus lygus:

$$
D=\sum_{i=1}^{n} D_{i}=\sum_{i=1}^{n}\left(a_{i} \sum_{j=1}^{s_{j}} q_{i j} p_{i j}-\bar{a}_{i} \sum_{j=1}^{s_{i}}\left(y_{i}-q_{i j}\right) p_{i j}+a_{i} y_{i} \sum_{j=s_{i}+1}^{m_{i}}+b_{i} \sum_{j=s_{i}+1}^{m_{i}}\left(q_{i j}-y_{i}\right) p_{i j}\right)
$$
[5].

Reikia parinkti tokius $y_{i}(i=1,2,3, \ldots, n)$, kad funkcija (vidutinis pelnas) $D(5)$ igytų didžiausią reikšmę

Panagrinèsime atveji, kai $y_{i}$ ir $y_{j}(i \neq j)$ tarp savęs "nepriklausomi", t.y. viens kito pakeisti negali.

Tam, kad rasti funkcijos (5) maksimumą, pakanka kiekvienai $i$-jai rušiai darbų (pvz., mūro) rasti didžiausią reikšmę:

$$
D_{i}\left(y_{i}\right)=a_{i} \sum_{j=1}^{s_{i}} q_{i j} p_{i j}-\bar{a} \sum_{j=1}^{s_{1}}\left(y_{i}-q_{i j}\right) p_{i j}+a_{i} y_{i} \sum_{j=s_{i}+1}^{m_{i}} p_{i j}+b_{i} \sum_{j=s_{i}+1}^{m_{i}}\left(q_{i j}-y_{i}\right) p_{i j}
$$

Jeigu $a_{i}>b_{i}$, tai:

1) $D_{i}\left(y_{i}\right) \leq a_{i} q_{i m_{i}}$, čia $a_{i} q_{i m_{i}}$ - galimas didžiausias pelnas su tikimybe $p_{i m_{i}}$ (didžiausias rizikos laipsnis $1-p_{i m_{i}}$, kai $\left.y_{i}=p_{i m_{i}}\right)$;

2) $D_{i}\left(y_{i}\right) \geq b_{i} q_{i 1}$, čia $b_{i} q_{i 1}$ - galimas mažiausias pelnas, kai $y_{i}=0$;

3) "atsargiausias" sprendimo variantas: $y=y_{i 1}$, tada

$$
D_{i}\left(y_{i}\right)=D_{i}\left(q_{i 1}\right)=a_{i} q_{i 1}+b_{i} \sum_{j=1}^{m_{i}}\left(q_{i j}-q_{i 1}\right) p_{i j} .
$$

4) "pesimistiškiausias" - pelnas $d_{i} y_{i 1}$, kuris gali būti gautas su tikimybe $p_{i 1}$, kai $y_{i}=y_{i 1}$ (čia rizikos laipsnis $\left.1-p_{i 1}\right)$.

Pagal duotos funkcijos uždarame intervale maksimalios reikšmès radimo taisyklę, funkcija (5) igys didžiausią reikšmę intervalo $\left[q_{i s_{i}} ; q_{i s_{i}+1}\right]$ gale, t.y. $y_{i}=q_{i s_{i}}$ arba $y_{i}=q_{i s_{i}+1}$, kadangi šiame intervale funkcija (6) yra tiesinè.

Atlikę funkcijos (6) algebrinius pertvarkymus gausime, kad

$$
D_{i}\left(y_{i}\right)=A_{i s_{i}}+B_{i s_{i}} y_{i}
$$


Šioje formuleje dydis $A_{i s,}$ yra lygus

$$
A_{i s_{i}}=a_{i} \sum_{j=1}^{s_{i}} q_{i j} p_{i j}+\bar{a}_{i} \sum_{j=1}^{s_{i}} q_{i j} p_{y j}+b_{1} \sum_{j=s_{i}+1}^{m_{i}} q_{i j} p_{i j}=\left(a_{i}+\bar{a}_{i}\right) \sum_{j=1}^{s_{i}} q_{i j} p_{i j}+b_{i} \sum_{j=s_{i}+1}^{m_{i}} q_{i j} p_{i j} .
$$

Formulëje (7) dydis $B_{i s,}$ yra lygus

$$
B_{i s_{i}}=a_{i} \sum_{j=s_{i}+1}^{m_{i}} p_{i j}-\bar{a}_{i} \sum_{j=1}^{s_{i}} p_{i j}-b_{i} \sum_{j=s_{i}+1}^{m_{i}} p_{i j}=\left(a_{i}-b_{i}\right) \sum_{j=s_{i}+1}^{m_{i}} p_{i j}-\bar{a}_{i} \sum_{j=1}^{s_{i}} p_{i j} .
$$

Galilmi šie (7) funkcijos atvejai:
a) $B_{i s_{i}}<0$;
b) $B_{t s_{1}}=0$;
c) $B_{i s_{1}}>0$

\section{Panagrinékime kiekvieną iš jų atskirai.}

Atveïs a. Siuo atveju $D_{i}\left(y_{i}\right)=B_{i s_{i}}<0$, todèl funkcija (7) intervale $\left[q_{i s_{i}} ; q_{i s_{i}+1}\right]$ yra mažejanti. Vadinasi, didžiausią jos reikšmę gausime, kai $y_{i}=q_{i s_{i}}$.

Pažiūrèsime, kaip pasikeis funkcija (7), kai $s_{i} \geq 1$.

1) $s_{i}=1$. Funkcijos (7) didžiausia reikšmè bus lygi:

$$
D_{i}\left(q_{i 1}\right)=A_{i 1}+B_{i 1} q_{i 1}
$$

2) $s_{i}>1$. Šiuo atveju pereiname prie funkcijos (7) nagrinejimo intervale $\left[q_{i s_{i}-1} ; q_{i s_{i}}\right]$. Vietoje funkcijos (7) turesime

$$
D_{i}\left(y_{i}\right)=A_{i s_{i}-1}+B_{i s_{i}-1} y_{i}
$$

Šioje formuleje dydis $A_{i s_{i}-1}$ yra lygus:

$$
A_{i s_{i}-1}=A_{i s_{i}}-a_{i} q_{i s_{i}} p_{i s_{i}}-\bar{a}_{i} q_{i s_{i}} p_{i s_{i}}+b_{i} q_{i s_{i}} p_{i s_{i}}=A_{i s_{i}}-\left(a_{i}+\bar{a}_{i}-b_{i}\right) q_{i s_{i}} p_{i s_{i}}
$$

Formulèje (10) dydis $B_{i s_{i}-1}$ yra lygus:

$$
B_{i s_{i}-1}=B_{i s_{i}}+a_{i} p_{i s_{i}}+\bar{a}_{i} p_{i s_{i}}-b_{i} p_{i s_{i}}=B_{i s_{i}}+\left(a_{i}+\bar{a}_{i}-b_{i}\right) p_{i s_{i}}
$$

Atveiis b. Šiuo atveju $D_{i}^{\prime}\left(y_{i}\right)=0$, todèl funkcija (7) intervale $\left[q_{i s_{1}} ; q_{i s_{t}+1}\right]$ yra pastovi $\left(D_{i}\left(y_{i}\right)=\right.$ const $)$ ir, vadinasi, $y_{i}$ gali būti bet koks skaičius iš minèto intervalo.

Atvë̈s c. Šiuo atveju $D_{i}^{\prime}\left(y_{i}\right)=B_{i s_{i}}>0$ ir funkcija (7) intervale $\left[q_{t s_{i}} ; q_{i s_{i}+1}\right]$ yra didejanti. Maksimalią reikšmę tokiu atveju ji igis, kai $y_{t}=q_{i s_{i}+1}$. Jeigu $s_{i+1}=m_{i}$, tada didžiausia funkcijos (7) reikšmé bus lygi:

$$
D_{i}\left(q_{i m_{i}}\right)=A_{i m_{i}}+B_{i m_{i}} q_{i m_{i}}
$$

Jeigu $s_{i+1}<m_{i}$, pereiname prie funkcijos (7) nagrinejımo intervale $\left[q_{i s_{1}+1} ; q_{i s_{i}+2}\right]$. Siuo atveju funkcija (7) bus lygi:

$$
D_{i}\left(y_{i}\right)=A_{i s}+B_{i s_{i}+1} y_{i}
$$

Šioje formuleje dydžiai $A_{i s_{1}+1}$ ir $B_{i s_{i}+1}$ atitinkamai bus lygūs:

$$
\begin{gathered}
A_{i s_{i}+1}=A_{i s_{t}}+a_{i} q_{i s_{i}+1} p_{i s_{i}}+\bar{a}_{i} q_{i s_{i}+1} p_{i s_{t}+1}-b_{i} q_{i s_{t}+1} p_{i s_{t}+1}=A_{i s_{i}}+\left(a_{t}+\bar{a}_{i}-b_{i}\right) q_{i s_{i}+1} p_{i s_{i}+1} \\
B_{i s_{i}+1}=B_{i s_{i}}-a_{i} p_{i s_{t}+1}-\bar{a}_{t} p_{i s_{i}+1}+b_{i} p_{i s_{t}+1}=B_{i s_{i}}-\left(a_{t}+\bar{a}_{i}-b_{i}\right) p_{i s_{i}+1}
\end{gathered}
$$


Atliksime funkcijos (7) variantų analizès rezultatų grafinę interpretaciją.

1) jeigu $a_{i}+\bar{a}_{i}-b_{i}>0$, tada iš formulių (12) ir (14) gausime, kad $B_{i 1}>B_{i 2}>B_{i 3}>\ldots>B_{i m_{i}}$. Funkcijos $D_{i}\left(y_{i}\right)$ grafikas atrodys taip (4 pav.):

4 pav. Funkcijos $D_{i}\left(y_{i}\right)$ grafikas,

kai $a_{i}+\bar{a}_{i}-b_{i}>0$

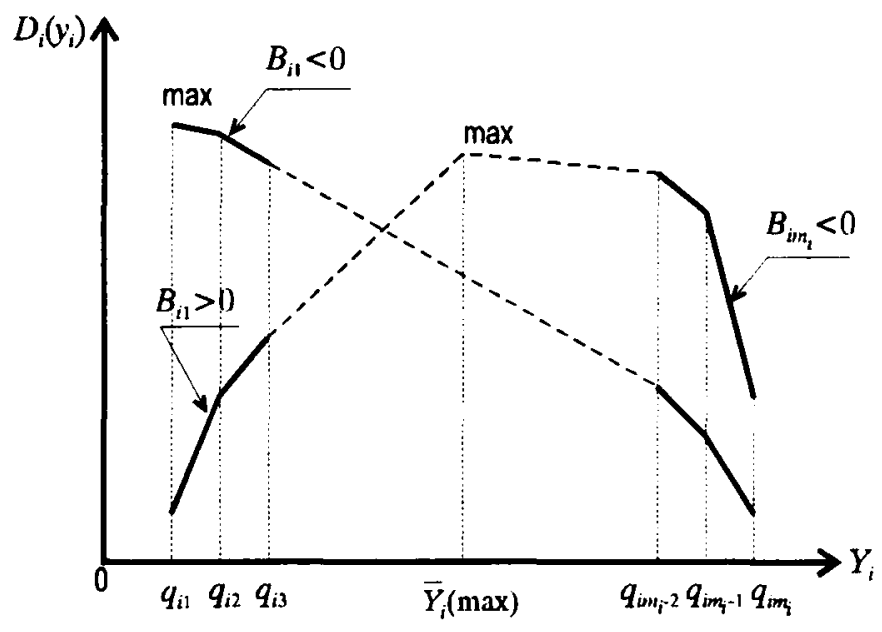

2) $a_{i}+\bar{a}_{i}-b_{i}=0$. İ̌ formuliu (12) ir (14) gausime, kad $B_{i 1}=B_{i 2}=B_{i 3}=\ldots=B_{i m_{i}}$. Funkcijos $D_{i}\left(y_{i}\right)$ grafikas atrodys taip (5 pav.):

5 pav. Funkcijos $D_{i}\left(y_{i}\right)$ grafikas, kai $a_{i}+\bar{a}_{i}-b_{i}=0$

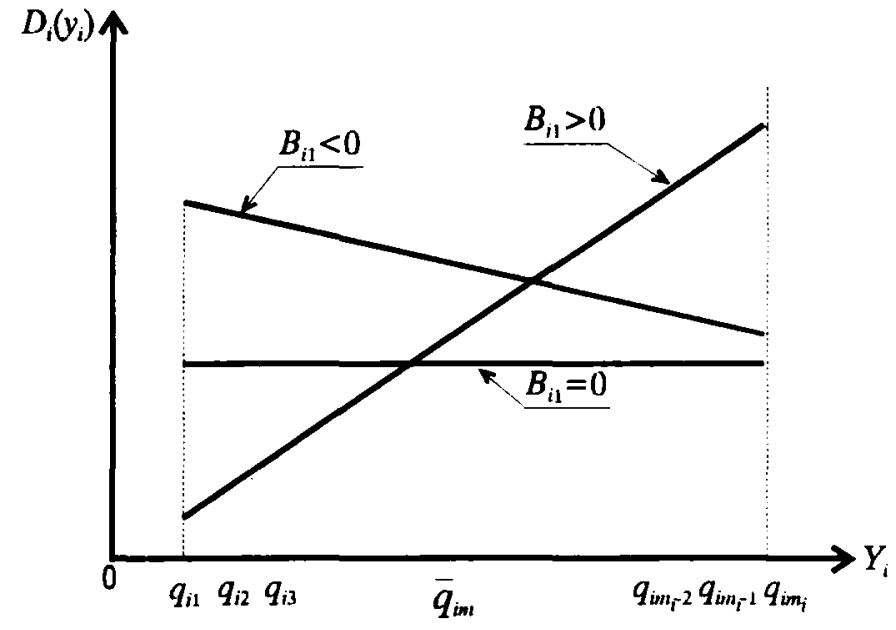

3) $a_{i}+\bar{a}_{i}-b_{i}<0$, tada is formuliu (12) ir (14) gausime, kad $B_{i 1}<B_{i 2}<B_{i 3}<\ldots<B_{i m_{i}}$. Funkcijos $D_{i}\left(y_{i}\right)$ grafikas atrodys taip (6 pav.):

6 pav. Funkcijos $D_{i}\left(y_{i}\right)$ grafikas, kai $a_{i}+\bar{a}_{i}-b_{i}<0$

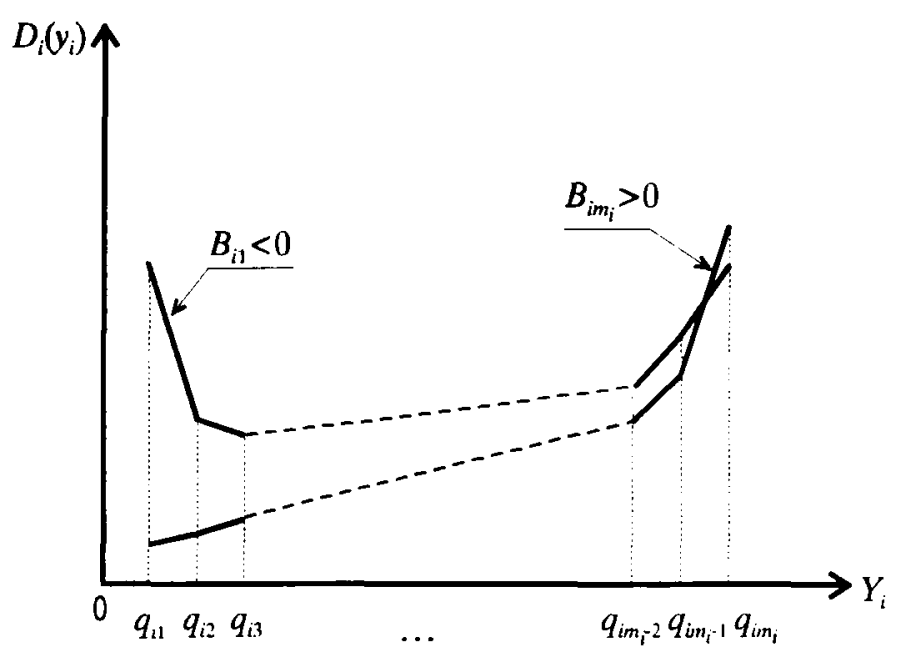


Iš 4 pav. matosi, kad, kai $a_{i}+\bar{a}_{i}-b_{i}>0$, skaičiavimus pradèti reikia nuo $B_{i 1}$ nustatymo.

1) Jeigu $B_{i 1} \leq 0$, tai $y_{i}=y_{i \max }=q_{i 1}$ ir maksimali vidutiné pelno reikšme $i$-jai grupei bus lygi:

$$
\max D_{i}\left(y_{i}\right)=D_{i}\left(q_{i 1}\right)=a_{i} q_{i 1} p_{i 1}+b_{i} \sum_{j=1}^{m_{i}} q_{i j} p_{i j}
$$

2) Jeigu $B_{i 1}>0$, nuosekliai skaičiuojame koeficientus $B_{i 2}, B_{i 3}, \ldots, B_{i m_{i}}$ iki tol, kol gausime pirmaji $B_{i k} \leq 0$. Tada

$$
y_{i}=y_{i \max }=q_{i k}
$$

Iš 5 pav. matosi, kad, kai $a_{i}+\bar{a}_{i}-b_{l}=0$, tai

$$
y_{i}=y_{i \max }=\left\{\begin{array}{lll}
q_{i 1}, & \text { jeigu } & B_{i 1}<0 \\
q_{i m_{i}}, \text { jeigu } & B_{i 1} \geq 0
\end{array}\right.
$$

Pastebèsime, kad jei $B_{i 1}=0$, tai $y_{i}=y_{i \max }$ gali būti bet koks skaičius iš rinkinio $q_{i 1}, q_{i 2}, \ldots, q_{i m_{i}}(2$ lentelè) arba bet koks skaicius iš intervalo $\left[q_{1} ; q_{i m_{i}}\right]$.

Iš 6 pav. matosi, kad, kai $a_{i}+\bar{a}_{i}-b_{i}<0$, skaičiavimus vél pradéti reikia nuo $B_{i 1}$ nustatymo:

1) jeigu $B_{i 1} \leq 0$, tai $y_{i}=y_{\text {imax }}=q_{i m}$,

2) jeigu $B_{i 1}<0$, reikia surasti funkcijos $D_{i}\left(y_{i}\right)$ reikšmes intervalo $\left[q_{1} ; q_{i m_{i}}\right]$ galuose ir priimti tą sprendimą, kuriam ši funkcija igyja didesnę reikšmę.

Pastebèsime, kad atvejis, kai $a_{i}+\bar{a}_{i}-b_{i}<0$, daugiau ịmanomas teoriškai negu praktiškai, nes turime, kad arba pelnas, kuṛ už atliktą darbą gaus nuosavi laikini padaliniai bus didesnis palyginti su tuo, kurį turètų "branduolio" padaliniai, arba darbai, atliekami "nenaudinguose” objektuose yra pakankamai pelningi.

\section{Statybos ịmonès gamybinès struktūros "branduolio" nustatymo skaitiniai pavyzdð̌iai}

Sakykime, kad per nagrinèjamą laikotarpi $T$ numatoma atlikti mūro darbus, kurių apimtis SI ekspertai ịvertino atitinkamomis tikimybèmis (3 lentelè).

3 lentelè. Duomenys (sqłyginiai) nuosavı̨ pastoviai veikiančị mūro padaliniu optimalioms darbų apimtims nustatyti

\begin{tabular}{llllll}
\hline$q_{i}$ & 200 & 300 & 400 & 500 & 600 \\
\hline$p_{i}$ & 0,2 & 0,4 & 0,2 & 0,1 & 0,1 \\
\hline
\end{tabular}

Nustatysime toki padalinių, atliekančių mūro darbus, pajègumą, kuris užtikrins maksimalų laukiamą vidutinị pelną.

Skaičiavimus atliksime keliems parinktiems būdingiems galimo pelno $a, \bar{a}$ ir $b$ variantams (4 lentelè).

4 lentelè. Laukiamo pelno už atliktus mũro darbus variantai priklausomai nuo padalinio pobūdžio (duomenys sąlyginiai)

\begin{tabular}{ccccccccc}
\hline Variantas & I & II & III & IV & V & VI & VII & VIII \\
\hline$a$ & 10 & 10 & 10 & 10 & 10 & 10 & 10 & 10 \\
$\bar{a}$ & 8 & 2 & -4 & -4 & 0 & 2 & 1 & -1 \\
$b$ & 6 & 5 & 6 & 8 & 6 & 12 & 12 & 12 \\
\hline
\end{tabular}

Variantas I. Sakykime, kad $200 \leq y \leq 300$. Skaičiavimus atliksime pagal (7-9) formules. Pagal formulę (7) turime, kad:

$$
D(y)=A_{1}+B y .
$$


Kadangi šiuo atveju nagrinejame pirmaji intervalą, $S_{i}=1$. Remdamiesi (8) ir (9) formulèmis, nustatysime koeficientus $A_{1}$ ir $B_{1}$ :

$$
\begin{gathered}
A_{1}=10 \cdot 200 \cdot 0,2+8 \cdot 200 \cdot 0,2+6(300 \cdot 0,4+400 \cdot 0,2+500 \cdot 0,1+600 \cdot 0,1)=2580 \\
B_{1}=(10-6)(0,4+0,2+0,1+0,1)-8 \cdot 0,2=1,6 .
\end{gathered}
$$

Gavome, kad, kai $200 \leq y<300, D(y)=2580+1,6 y$.

Sakykime, kad $300<y \leq 400$, t.y. pereiname prie antrojo intervalo. Tada ieškoma funkcija $D(y)$ atrodys taip:

$$
D(y)=A_{2}+B_{2} y
$$

Remdamiesi formulemis (7-9), surasime koeficientus $A_{2}$ ir $B_{2}$ :

$$
\begin{gathered}
A_{2}=A_{1}+(a+\bar{a}-b) q_{2} p_{2}=2580+(10+8-6) \cdot 300 \cdot 0,4=4020, \\
B_{2}=B_{1}-(a+\bar{a}-b) p_{2}=1,6-(10+8-6) \cdot 0,4=-3,2 .
\end{gathered}
$$

Gavome, kad, kai $300<y \leq 400, D(y)=4020-3,2 y$.

Sakykime, kad $400<y \leq 500$, t.y. pereiname prie trečiojo intervalo. Tada ieškoma funkcija $D(y)$ atrodys taip:

$$
D(y)=A_{3}+B_{3} y
$$

Remdamiesi formulemis (8) ir (9), surasime koeficientus $A_{3}$ ir $B_{3}$ :

$$
\begin{gathered}
A_{3}=A_{2}+(a+\bar{a}-b) q_{3} p_{3}=4020+(10+8-6) \cdot 400 \cdot 0,2=4980, \\
B_{3}=B_{2}-(a+\bar{a}-b) p_{3}=-3,2-1,2 \cdot 0,2=-5,6 .
\end{gathered}
$$

Gavome, kad, kai $400<y \leq 500, D(y)=4980-5,64 y$.

Panašiai surandame, kad, kai $500<y \leq 600$, funkcija $D(y)$ bus lygi:

$$
D(y)=5580-6,8 y \text {. }
$$

Taigi gavome toki funkcijos $D(y)$ pavidalą:

$$
D(y)=\left\{\begin{array}{l}
2580+1,6 y, \text { kai } 200 \leq y \leq 300, \\
4020-3,2 y, \text { kai } 300<y \leq 400, \\
4980-5,6 y, \text { kai } 400<y \leq 500, \\
5580-6,8 y, \text { kai } 500<y \leq 600
\end{array}\right.
$$

Pastebèsime, kad, kai kintamojo $y$ reikšmè yra lygi laukiamai mūro darbų apimčiai, t.y. didesnei negu 200 ir mažesnei negu 600, tai funkcijos $D(y)$ reikšmę galime nustatyti dviem būdais. Šią aplinkybę panaudosime skaiciavimų kontrolei.

Pavyzdžiui, tegu $y=300$, tada

$$
\begin{aligned}
& D(300)=2580+1,6 \cdot 300=3060 \text { (I būdas), } \\
& D(300)=4020-3,2 \cdot 300=3060 \text { (II būdas). }
\end{aligned}
$$

Skaičiavimų rezultatai sutampa, ir tai rodo, kad klaidos nepadaryta. 
Gautos funkcijos grafikas duotas 7 pav.

Turime, kad $\max D(y)=D(300)=3060$, ir $y_{\max }=300$. Pastebèsime, kad $y_{\max }<q=350$.

Variantas II. Siuo atveju $a=10 ; \quad \bar{a}=2, b=5$ (4 lentelè).

Atlikę pirmam variantui analogiškus skaičiavimus, gausime:

$$
D(y)=\left\{\begin{array}{l}
2030+3,6 y, \text { kai } 200 \leq y \leq 300, \\
2870+0,8 y, \text { kai } 300<y \leq 400, \\
3430-0,6 y, \text { kai } 400<y \leq 500, \\
3780-1,3 y \text {, kai } 500<y \leq 600 .
\end{array}\right.
$$

Turime, kad $y_{\max }=400 ; D(400)=3190$. Gautos funkcijos grafikas duotas 7 pav.

Variantas III. Šiuo atveju $a=10 ; \bar{a}=-4 ; b=6$, t.y. $a+\bar{a}-b=0$.

Gavome, $\operatorname{kad} D(y)=2100+4 y$, kai $200 \leq y \leq 600$. Gautos funkcijos grafikas duotas 7 pav.

Variantas IV. Šiuo atveju $a=10 ; \quad \bar{a}=-4 ; b=8$, t.y. $a+\bar{a}-b<0$.

Gavome, kad

$$
D(y)=\left\{\begin{array}{l}
2720+2,4 y, \text { kai } 200<y \leq 300, \\
2480+3,2 y, \text { kai } 300<y \leq 400, \\
2320+3,6 y, \text { kai } 400<y \leq 500, \\
2220+3,8 y, \text { kai } 500<y \leq 600 .
\end{array}\right.
$$

Gautos funkcijos grafikas duotas 8 pav.

Variantas V. Siuo atveju $a=10 ; \bar{a}=0 ; b=6$.

Gavome, kad

$$
D(y)=\left\{\begin{array}{l}
2260+3,2 y, \text { kai } 200 \leq y \leq 300, \\
2740+1,6 y \text {, kai } 300<y \leq 400 \\
3060+0,8 y \text {, kai } 400<y \leq 500 \\
3260+0,4 y, \text { kai } 500<y \leq 600
\end{array}\right.
$$

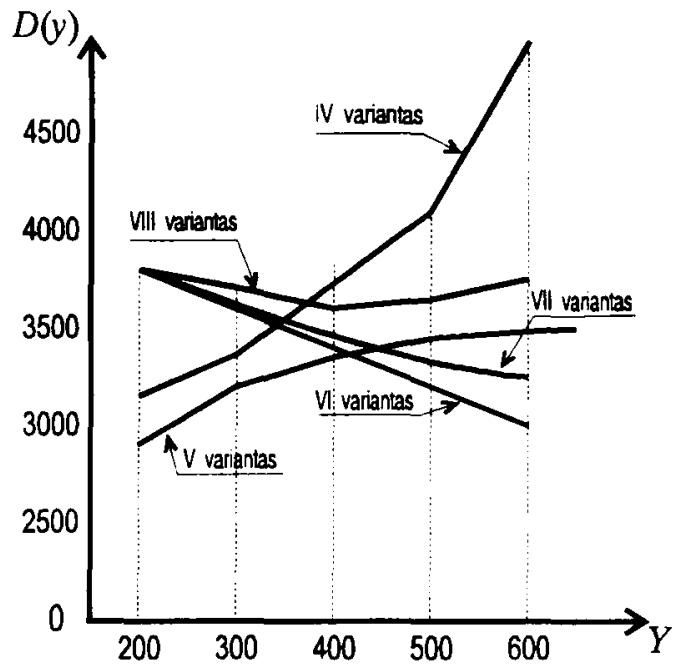

8 pav. Funkcijos $D(y)$, paskaičiuotos 4 lentelès IV-VIII variantams, grafikai

Gautos funkcijos grafikas duotas 8 pav.

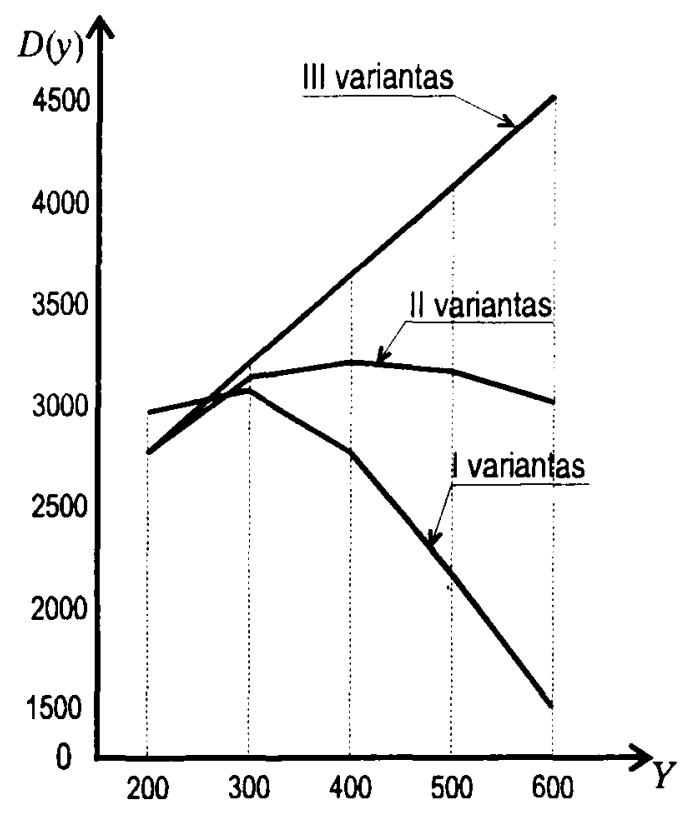

7 pav. Funkcijos $D(y)$, paskaiciuotos 4 lentelès I-III variantams, grafikai

Variantas VI Šuo atveju $a=10 ; \bar{a}=2 ; b=12$, t.y. $B_{1}<0$ ir $a+\bar{a}-b=0$.

Gavome, kad

$$
\begin{aligned}
& D(y)=4200-2 y, \text { kai } 200 \leq y \leq 600, \\
& D(200)=4200-2 \cdot 200=3800, \\
& D(600)=4200-2 \cdot 600=3000 .
\end{aligned}
$$

Gautos funkcijos grafikas duotas 8 pav. 
Variantas VII. Šiuo atveju $a=10 ; \bar{a}=1 ; b=12$, t.y. $B_{1}<0$ ir $a+\bar{a}-b<0$.

Gavome, kad

$$
D(y)=\left\{\begin{array}{l}
4160-1,8 y, \text { kai } 200 \leq y \leq 300, \\
4040-1,4 y, \text { kai } 300<y \leq 400, \\
3960-1,2 y, \text { kai } 400<y \leq 500, \\
3910-1,1 y, \text { kai } 500<y \leq 600
\end{array}\right.
$$

Gautos funkcijos grafikas duotas 8 pav.

Variantas VIII. Šiuo atveju $a=10 ; \bar{a}=-1 ; b=12$.

Gavome, kad

$$
D(y)=\left\{\begin{array}{l}
4080-1,4 y, \text { kai } 200 \leq y \leq 300, \\
3720-0,2 y, \text { kai } 300<y \leq 400, \\
3480+0,4 y, \text { kai } 400<y \leq 500 \\
3330+0,7 y, \text { kai } 500<y \leq 600
\end{array}\right.
$$

Gautos funkcijos grafikas duotas 8 pav.

\section{Statybos ịmonès gamybinès struktüros "branduolio" dydžio skgičiavimo rezultaty interpretavimas}

Skaičiuojant statybos įmonés gamybinès struktūros "branduolio" dydį, buvo paimti aštuoni variantai, besiskyriantys vienas nuo kito nuosavų laikinų padalinių darbo efektyvumu $\left(b_{i}\right), o$ taip pat nustoliais, kuriuos patirtu SI dèl to, kad nuosavi pastoviai veikiantys padaliniai kuri laiką bus nevisiškai apkrauti darbu $\left(a_{i}\right)$. Tam, kad išrył̌kinti dèsningumus ir padaryti atitinkamas išvadas, sudarysime atitinkamą lentelę (5 lentelè).

5 lentelè. Statybos jmonès gamybinès struktūros "branduolio" dydžio skaičiavimo suvestiniai rezultatai

\begin{tabular}{ccccc}
\hline Variantas & $D(y)(\max )$ & $y$ & $a-b$ & $\bar{a}$ \\
\hline 1 & 3060 & 300 & 4 & 8 \\
2 & 3190 & 400 & 5 & 2 \\
3 & 4500 & 600 & 4 & -4 \\
4 & 4500 & 600 & 2 & -4 \\
5 & 3500 & 600 & 4 & 0 \\
6 & 3800 & 200 & 2 & 2 \\
7 & 3800 & 200 & 0 & 1 \\
8 & 3800 & 200 & 2 & -1 \\
\hline
\end{tabular}

5 lentelèje pateiktų skaičiu analizè leidžia padaryti šias dvi pagrindines išvadas:

1) augant nuostoliams, kuriuos patiria statybos imonè dèl to, kad atitinkami "branduolio" padaliniai per nagrinèjamą laikotarpi $T$ bus nevisiškai apkrauti darbu $\left(a_{i}\right)$, jo dydis mažejja;

2) kuo didesnis "branduolio" padalinių darbo efektyvumas palyginus su nuosavų laikinų padaliniu darbu, tuo labiau auga "branduolio" dydis.

Šios skaičiavimais patvirtintos išvados neprieštarauja logikai.

Žinant optimalias "branduolio" padalinių atliekamas darbų apimtis, t.y. apimtis, kurios duoda didžiausią vidutini pelną, galima nustatyti jo dydị. Atlikti tyrimai parodè, kad dabartiniame statybos gamybos išvystymo etape prie pasiekto darbų mechanizavimo laipsnio statybos įmonés ar jos gamybinio padalinio dydị tiksliausiai parodo dirbančiuju skaičius $[2,6,7]$. Turint darbų apimtis ir jas atitinkančias darbo sąnaudas, ji galima nustatyti taip [1]:

$$
D_{i}=\frac{S_{G P_{i}}}{T}
$$


c̆a $D_{i}$ - statybos imonès (i-o jos gamybinio padalinio) dydis, žm.; $S_{G P_{i}}$ - gamybinés programos ( $i$-s darbu rūšiai) darbo sąnaudos, žm.; $T$ - nagrinéjamas laikotarpis, d.d.

Po statybos įmonès "branduolio" ir vykdomos gamybinès programos dydžio nustatymo prasideda jo struktūrizavimo, t.y. padalinių specializavimo atlikti tam tikrą darbų rūši, taip pat laikinų nuosavų padaliniu formavimo etapas. Jo tikslas - pasiekti, kad SI gamybiniai struktūros padalinių dydžio proporcijos atitiktu vykdomos gamybinés programos proporcijas.

\section{Išvados}

Šiuo metu išryškejjo keli principiniai statybos įmoniụ organizaciniu struktūrų modeliai - kraštutiniai, kai SI visiškai neturi savo gamybinių padaliniu arba kai savo jègomis siekia atlikti visą su objektų statyba susijusi darbu kompleksą, ir tarpiniai, kai derinami abu pirmieji variantai.

Perspektyviausias yra pastarasis, kombinuotas. Šiuo atveju statybos i̇monę, siekiančią prisiderinti prie nuolat plačiose ribose svyruojančio gamybinès programos dydžio, sudaro "branduolys" (nuosavi nuolat veikiantys) ir nuosavi laikini gamybiniai padaliniai. Tokios SĮ komercinès-ūkinès veiklos rezultatai didele dalimi priklauso nuo "branduolio" bei nuo nuosavų laikinu padaliniu skaičiaus ir dydžio santykio. Tam, kad ji nustatyti, reikia išspręsti optimizavimo uždavini, t.y. apskaičiuoti, kokių darbų apimtị per nagrinejjamą laikotarpi turi atlikti statybos ịmonès "branduolio" padaliniai, kad gautas vidutinis pelnas būtų didžiausias.

Skaičiavimu rezultatai parodé, kad: 1) augant nuostoliams, kuriuos patiria statybos imoné dèl to, kad "branduolio" padaliniai tam tikrais laiko tarpais nepilnai apkraunami darbu, jo dydis mažèja; 2) kuo didesnis "branduolio" padaliniy darbo efektyvumas palyginus su nuosavy laikiny padaliniy darbu, tuo labiau auga "branduolio" dydis.

\section{Literatūra}

1. R.Ginevičius. Statybos imoniu gamybinès struktūros reorganizavimo ypatumai // 4-sios tarptautinés konferencijos "Naujos statybinès medžiagos, konstrukcijos ir technologijos", ivykusios Vilniuje 1995 m. gegužes 10-13 d., straipsniai. I t. Vilnius: Technika, 1995, p. 253-258.

2. Р.Гинявичюс. Методология определения размера строительной организации. Деп. в ЛитНИИНТИ. Вильнюс, 1988. $18 \mathrm{c}$.

3. R.Ginevičius. Statybos ir montavimo organizaciju parametrụ tarpusavio ryšio ypatumai // LTSR aukštuju mokyklu mokslo darbai. Statybos ekonomika ir organizavimas. Nr. 17. Statybos efektyvumo problemos. Vilnius: Mintis, 1990, p. 18-24.

4. J.Kubilius. Tikimybiy teorija ir matematine statistika. Vilnius: Mokslas, 1980. 408 p.

5. Tintner G. The use of Stochastic Linear Programming in Planing // The Indian Economic Review, 5, No 2, 1960, p. $36-45$.

6. A.Kieser, H.Kubicek. Organisation. Berlin, New York, 1992. 530 S.

7. M.H.Mescon, M.A.Albert, F.Khedouri. Management. 3 rd. ed. N.Y. Harpert Row. Publishers, 1988. 777 p.

Iteikta 19960215

\section{BUILDING ENTERPRISES INDUSTRIAL STRUCTURE'S OPTIMISATION}

\section{R. Ginevičius, S. Čirba}

S u m m a I y

Building enterprises industrial programme which is muolded by the way of competition, could hesitate in rather wide limits: in its quantity and expenditure of labour structure. It is possible to expect high results of activity only then, if building enterprises would be able to adjust properly near changeable environment. You could do this only if you reorganisate its industrial structure. Two sides could be responsible for this formation-constant and changeable. The first side must ensure enterprises potential, the high works quantity and paces. The second one must compensate industrial programme scale and structures hesitation. If you want to find awarded parts quantity you must solve optimisation problem it means to define what volume of works during the analysing period must do its "nucleus" units that the recieved profit would be the greatest one. 